\title{
Strategic Entrepreneurship Framework for Small and Medium Enterprises
}

\section{Nurulhuda Abu Bakar, Wan Normeza Wan Zakaria and Siti Haida Ismail}

To Link this Article: http://dx.doi.org/10.6007/IJARBSS/v11-i11/11247

DOI:10.6007/IJARBSS/v11-i11/11247

Received: 07 September 2021, Revised: 02 October 2021, Accepted: 22 October 2021

Published Online: 06 November 2021

In-Text Citation: (Bakar et al., 2021)

To Cite this Article: Bakar, N. A., Zakaria, W. N. W., \& Ismail, S. H. (2021). Strategic Entrepreneurship Framework for Small and Medium Enterprises. International Journal of Academic Research in Business and Social Sciences, 11(11), $418-432$.

Copyright: (c) 2021 The Author(s)

Published by Human Resource Management Academic Research Society (www.hrmars.com) This article is published under the Creative Commons Attribution (CC BY 4.0) license. Anyone may reproduce, distribute, translate and create derivative works of this article (for both commercial and non-commercial purposes), subject to full attribution to the original publication and authors. The full terms of this license may be seen at: http://creativecommons.org/licences/by/4.0/legalcode

Vol. 11, No. 11, 2021, Pg. $418-432$

Full Terms \& Conditions of access and use can be found at http://hrmars.com/index.php/pages/detail/publication-ethics 


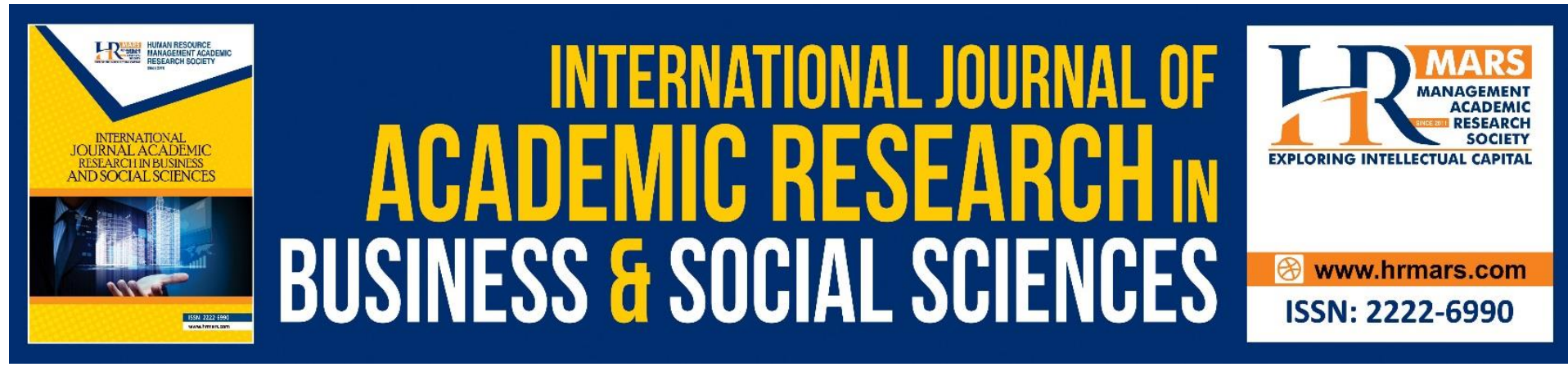

\title{
Strategic Entrepreneurship Framework for Small and Medium Enterprises
}

\author{
Nurulhuda Abu Bakar, Wan Normeza Wan Zakaria and Siti \\ Haida Ismail \\ Razak Faculty of Technology and Informatics, Universiti Teknologi Malaysia \\ Email: ivyinspired98@gmail.com,normeza.kl@utm.my, sitihaida@utm.my
}

\begin{abstract}
Small and medium enterprises (SME) businesses are important economic growing forces, particularly in Malaysia through their significant economic contribution towards business population and employment creation. The aim of this study is to develop a framework integrating fundamental strategic entrepreneurship elements that support business growth in the context of engineering or technology-based firms within the Malaysian SME sector. Through interviews with SME firm owners and senior management personnel, common strategic entrepreneurship practices that significantly influence business growth were identified and converged into a framework. Findings revealed that the main elements practiced by the SME firms can be categorized as People, External, Innovation Approach and Internal. People element was most referred to by the research participants, followed by the other elements respectively. A new model was developed to depict these elements and is referred to in this study as the PIIE Entrepreneurial Model. The most common limitation highlighted by the research participants was on the communication and collaboration gap between the older and younger generation of employees. The research participants also reacted to the financial challenges faced especially in terms of sourcing grants or funds for the businesses. This study should impart useful insights for policy makers and provide SME strategy practitioners or leaders with strategic entrepreneurship guidelines to help improve businesses and SME sector's competitiveness.
\end{abstract}

Keywords: Strategy, Entrepreneur, Strategic Entrepreneurship, SME, Business Growth

\section{Introduction}

SME businesses are important global economic growing forces and in Malaysia, the SME businesses contributed 38\% or RM521.7bil to the Gross Domestic Product (GDP) of RM1,361.5bil in 2018 (Department of Statistics Malaysia, 2019). SME firms make up about $99 \%$ of the total business population and contributes to $66 \%$ of the employment in Malaysia. However, the SME contribution of 38\% to the overall national GDP in 2019 is still considered as low, compared to other developed nations which have reported SME contribution in the range of $60 \%$ to $80 \%$ (Kamel, 2019). In terms of economic sectors, services and manufacturing sectors continue to be the main contributors to the overall Malaysian economic growth with the support of the civil engineering segment providing moderate growth to the 
manufacturing sector (SME Annual Report, 2020). The importance of the engineering sector is also seen in China where the continuous development of SME engineering enterprises has contributed to the development of the economy through its global exports, economic sustainability, and innovation is seen to be as indispensable (Li et al., 2012).

Malaysia is expected to increase its SME contribution through various measures that support SME innovation and business growth such as financing ecosystem enhancement (Kamel, 2019). It is imperative for SME businesses to remain competitive since majority of Malaysian employees work for companies that fall within this sector. Financing collaboration efforts have been implemented to drive technology and innovation for SMEs to remain relevant, competitive and achieve business growth. These efforts include financing institutions' issuing grants to SME companies to support information and communications technology (ICT) adoption (SME Corp Malaysia, 2019). Notwithstanding the small business size nature, every SME firm plays a role in strengthening the economy since the stabilization and growth of small businesses can be aggregated into the overall growth of the economy (DeMartino et al., 2015).

More research is required to understand the growth in small businesses since the topic is still underdeveloped and to explore innovation strategy implementation within SME firms in emerging economies due to its lack thereof (DeMartino et al., 2015; Haddad et al., 2020). The strategy framework of an SME firm may also not be as effective as in its current business growth process. According to DeMartino et al. (2015), the heterogeneity of small businesses and their varying environments lead to uncertainty and complexity, in turn causing the study of growth to be more difficult to classify and generalize. Kyrgidou \& Hughes (2010) state that different sized companies face different conditions due to different resource-base, systems and structures. It is also suggested that strategic theories usually developed for bigger firms may not have the same outcome for smaller firms (Lumpkin \& Katz, 2007).

For the past three decades, there have been extensive independent studies done on entrepreneurship and strategy, which later evolved into a combination of both constructs (Kyrgidou \& Hughes, 2010; Luke et al., 2011). The strategic entrepreneurship (SE) model that was introduced in 2003 by Ireland et al (2003) has since developed further to an alternative one to address the linear limitation of the earlier model (Kyrgidou \& Hughes, 2010). Sun et al (2018) describe SE as an emerging new field due to the growing importance of entrepreneurship and creative destruction of the economy. In light of the growing research interest and contribution of SME sector to Malaysian GDP, this study aims to investigate SE practices by local SME businesses. This research is aligned towards achieving the following objectives:

- to explore the challenges and limitations faced by SME businesses

- $\quad$ to identify central SE elements through examination of current SME firms' practices

- $\quad$ to develop a practical SE framework that is applicable to the SME sector

The data collection activity is focused on engineering and technology-based businesses in view of their supporting roles in the national policy execution of Industry 4.0 (IR4.0). This policy envisions higher value-added process, digitization, advanced manufacturing technologies and efficient resource utilization to provide greater opportunities for SME firms and drive competitiveness for Malaysia (Industry4WD, 2020). 


\section{Literature Review}

a) Strategy

There has been extensive research on strategic planning and how it complements a business, and its role and contribution towards the success of a business. Five categories have been considered as important contributors to entrepreneurial outcomes; (i) characteristics of entrepreneurs, (ii) the content of their strategies, (iii) the composition of teams, (iv) the availability and type of resources, and ( $v$ ) configurations of internal and external resources (Lumpkin \& Katz, 2007). Crockett et al (2007) study indicates that top management's support result in successful entrepreneurial strategies while the sharing of resources within a company significantly impacts entrepreneurial initiatives. In an organizational set-up, planning activity links to businesses performance and relates to entrepreneurial success as it promotes new venture emergence (Wei et al., 2018). However, small firms were said to practice strategy infrequently, sporadically, and reactively instead of formalized planning, hence the need to understand the relationship between innovative strategy-making with business performance (Verreynne \& Meyer, 2007). By understanding the strategic nature of an entrepreneurial process will help to explain the relationship between factors that create value and wealth for the organization (Lumpkin \& Katz, 2007).

\section{b) Entrepreneurship}

Entrepreneurship literature has been covered for a long time especially in term of its definition, its characteristics and what outcome it entails, namely wealth generation or nonfinancial related such as branding and image. The connection of resources, people, tradition and knowledge of entrepreneurship creates values and opportunities for the economy (Gaddefors \& Anderson, 2017). Study by Luke et al. (2011) describes two elements as the antecedents to entrepreneurship, namely innovation and identifying opportunities with growth being the outcome. Value creation or recognition process consists of three important variables; environment trends, characteristics of the entrepreneur and opportunity gap (Barringer \& Ireland, 2012). An effective entrepreneurial process requires a customized approach as this depends on varying factors such as the characteristics of the entrepreneur and dynamics of the environment (Fabian \& Ndofor, 2007).

\section{c) SE Constructs}

Ireland et al. (2003) formed an SE linear model comprising four dimensions; entrepreneurial mind set, entrepreneurial culture and leadership, strategic management of resources, and applying creativity to develop innovation. Entrepreneurship is synonym to innovation, opportunity and growth, while strategy is closely related to exploitation of opportunities, advantage-seeking, all in the pursuit of achieving competitive advantage (Ireland et al., 2003; Kyrgidou \& Hughes, 2010; Luke et al., 2011). Luke et al (2011) later established a framework to assess the level of SE within state-owned enterprises in New Zealand after taking into consideration a series of frameworks from past research. This framework represents a combination of variables involving central entrepreneurial elements, which are then applied in a strategic context which in turn, leads to the development of expertise within core skills and resources.

\section{d) Conceptual Framework}

Based on the linear SE model by Ireland et al. (2003), Kyrgidou \& Hughes (2010) had developed an SE model with an iterative approach that addresses the linear limitations and 
improves decision-making. This model represents the SE process that a firm undertakes to develop competitive advantage and to identify opportunities that lead to value creation through measured strategic actions. The five main elements present in the model are entrepreneurial, resource management, creativity and innovation, learning, and internal environment (Kyrgidou \& Hughes, 2010). Taking both models by Ireland et al. (2003) and Kyrgidou \& Hughes (2010) as its basis, this study seeks to capture the important elements that are relevant to SE practices in an SME landscape. The elements have been derived and detailed into four categories listed below.

\section{People}

People is one of the most important assets of an organization. Clegg (2018) states that people resources within an organization are seen as the source for all innovation, commercialization, and operationalization. Human resources require active recruitment, continuous training, and up-skilling to become more productive. SMEs' workforce makes up about $99 \%$ of the total business population in Malaysia. To manage this workforce, leaders play a critical role in ensuring employees are motivated and driven. Leadership capabilities, apart from resource fluidity and strategy sensitivity, is an inherent element to strategic agility in an SME context in order to achieve high level aspirations and goals alignment (Arbussa et al., 2017). Haddad et al (2020) state that leaders need to inculcate an innovative culture and encourage employees to always give ideas since ideas are the start of innovation.

\section{Internal}

A formalized growth planning plays a central role in the small businesses and this is critical for those firms with unstable sales and limited resources (DeMartino et al., 2015). Therefore, the leaders' strategic agility of a small firm and their planning qualities are integral to the firm as they structure the path to growth. Due to the SME firm's typical flatter organizational structure and lesser hierarchical levels, communication is smoother and resources can be more fluid resulting in faster response to changes (Arbussa et al., 2017). The growth outcome of a small medium-sized firm relates to how effective it utilizes and deploys internal resources and also by leveraging on its resources to innovate (Haddad et al., 2020). In order to have innovative products and services, Clegg (2018) has determined that by not having defined and effective processes will pose a constraint to an organization to produce trained, skilled and motivated process owners.

\section{Innovation Approach}

Lack of product service innovation is identified as one of the most common growthimpeding factors (Clegg, 2018). Innovation is an important component in the fundamental principles of SE and has the potential to improve business performance (Haddad at al., 2020; Kyrgidou \& Hughes, 2010). Through the study by Haddad et al (2020) on strategies undertaken by SMEs in implementing innovations to achieve performance goals, three critical areas were identified; innovative culture, identification of ideas, and recognition of customers as the resources to the organization. Particularly within the Malaysian SME landscape, innovation culture is recognized as the seed that needs to be planted in local organizations to enhance entrepreneurship (Hanifah et al., 2019). 


\section{External}

SME firms that offer products and service to the market need to understand market requirements by constantly communicating with customers and seeking their honest feedback or criticism (Haddad et al., 2020). Apart from improving efficiency and use of resources, Heikkilä et al. (2018) suggest that customer relationship, customer response and partnerships are important strategies for SMEs in building their business models.



Figure 1: SE Conceptual framework

Based on the four elements identified above, a conceptual framework has been developed with each element being represented by a quadrant illustrated in the chart (Figure 1).

\section{Methodology}

A qualitative data collection approach was adopted via semi-structured interviews involving five research participants, all of whom are senior management personnel directly involved in the SME firm's strategic management. The criterion-based purposive sampling method was implemented for this study where research participants had been deliberately selected based on criteria that best contribute to the study. The research participants had fulfilled the pre-determined criteria consisting of SME unique characteristics of revenue and manpower size defined by SME Corp Malaysia (n.d.) as well as the type of business that is categorized within the scope of engineering and technology. In order to understand the relationship between reputation and business cooperation in the SME sector, Franco \& Haase (2020) conducted semi-structured interviews with five representatives who fulfilled the SME criteria. This approach was used in view that the topic was unfamiliar, subjective and culturalrelated. Similarly, Haddad et al. (2020) explored innovation strategies within SME firms by interviewing five SME managers until data saturation was achieved. Therefore, for this study, a similar semi-structured interview method with a small set of research participants was selected since it also involves subjective elements such as human behavior and culture within an SME organizational set-up. 
Interview sessions were held with five research participants in the period of May to June 2021. Semi-structured questions were formulated based on the research objectives and used as a guideline during the interview sessions. This was to allow some freedom for the research participants to provide their responses and share their experiences comfortably. The key content of the interview guideline included questions with regards to the challenges and limitations experienced by the research participants and SE practices that exist in the organizations. A maximum of one-hour duration was allocated for each interview session. Table 1 shows the main characteristics of the five research participants (interviewees) of the selected SME firms. The completed interview transcriptions were then uploaded into a qualitative data analysis software, Quirkos (Quirkos 2.4.2, 2021) where the main and subthemes had been pre-defined to enable proper data classification. Figure 2 depicts the three main themes; (i) Challenges, (ii) Limitations and (iii) SE practices, while there are nine, five and four sub-themes corresponding to the main themes respectively. The interview content was coded respectively into the relevant themes for the data to be analyzed accordingly.

Table 1: Characteristics of research participants

\begin{tabular}{|c|c|c|c|c|c|}
\hline & $\begin{array}{l}\text { Interviewee } \\
\text { A }\end{array}$ & $\begin{array}{l}\text { Interviewee } \\
B\end{array}$ & $\begin{array}{l}\text { Interviewee } \\
\text { C }\end{array}$ & $\begin{array}{l}\text { Interviewee } \\
D\end{array}$ & $\begin{array}{l}\text { Interviewee } \\
E\end{array}$ \\
\hline Position & $\begin{array}{l}\text { Managing } \\
\text { Director }\end{array}$ & Firm owner & Firm owner & $\begin{array}{l}\text { Head of } \\
\text { Technical } \\
\text { Operations }\end{array}$ & Director \\
\hline Business sector & $\begin{array}{l}\text { Transport and } \\
\text { telecommunicati } \\
\text { on engineering }\end{array}$ & $\begin{array}{l}\text { Engineerin } \\
\text { g solutions }\end{array}$ & $\begin{array}{l}\text { Constructio } \\
\mathrm{n}\end{array}$ & $\begin{array}{l}\text { Transportatio } \\
\text { n Safety }\end{array}$ & $\begin{array}{l}\text { Software } \\
\text { Solutions } \\
\text { Engineering }\end{array}$ \\
\hline
\end{tabular}

\section{Main Canvas Views}

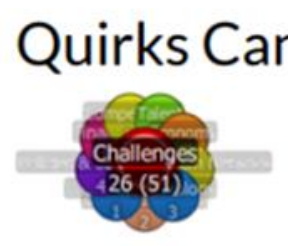

Main theme

Challenges

Sub-theme

Competition, talent, economy, supply chain network, technology, client perception, customization, policies \& bureaucracy, financial

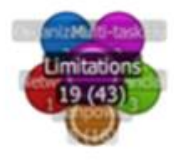

Main theme

People, Internal, Innovation Approach,

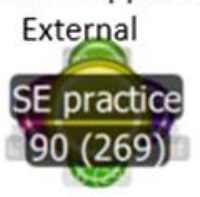

Limitation

Sub-theme

Multi-tasking, financial, manpower, network, organizational

Figure 2: Data coding themes extracted from Quirkos software 


\section{Findings}

a) External Challenges

There is a total of 26 codes or occurrences being mentioned by the research participants in 9 different categories of challenges namely competition, talent, economy, supply chain network, technology, client perception, customization, policies \& bureaucracy and financial. The most common challenges are difficulty in getting assistance from external bodies such as government grants and the support network for SMEs that is seen as not supportive enough, both of which may impede business growth. Limitation on business growth was reflected in the study in China which discussed the shortage of funds and low liquidity in manufacturing SMEs that had led to difficulty in recruiting high talents to propel their business growth (Li et al., 2012).

Since the companies are engineering and technology-based, it is important to keep up with the technology changes and prepare for IR4.0. However, policies and bureaucracy involved such as tender processes and policies, for example, foreign workers hiring policy versus automation incentive schemes by the government may also pose issues to business growth. Interviewee B, who is the founder of a technology-based firm, shared on how the performance of his automation service and product offerings may be affected by the labor policy if it works in favor of foreign labor recruitment.

Table 2: Selected Interview Responses to Challenges

\begin{tabular}{ll}
\hline Question & What are the main challenges your firm faced in \\
pursuing business growth in the SME sector? \\
Selected responses \\
"First and foremost, the challenges that we face \\
definitely is financial related. Because we started \\
off with our own, we pumped in our own money, all \\
the founders, who are directors and shareholders at \\
the moment. And we have since day one been trying \\
to secure grants from the government based on \\
their policy of industry 4.0 and whatnot. But \\
unfortunately, we have not been able to get any." \\
(Interviewee E, Director) \\
"So, at the end of the day, when it comes to policies, \\
having being able to hire foreigners at very low \\
costs, seems to be the determinant on whether to \\
adopt automation. Automation means less people, \\
or just hire, you know, low cost workers at \\
factories." (Interviewee B, Firm owner)
\end{tabular}

b) Internal Limitations

The greatest limitation faced by the companies is mainly attributed to manpower issues, with 3 sub-themes being classified as team motivation, generation gap and teamwork. Most research participants have highlighted on similar issues relating to generation gap issue. There is a mind-set gap between the older and the younger generation or millennials as reflected in the interview response excerpt below. There is a need to bridge the gap by getting both to collaborate effectively. Technology-based companies also require constant motivation amongst their employees to follow through new technologies breakthroughs. 
Interviewee B stressed on the importance of being motivated in order to convince clients of the firm's capabilities in providing the right product.

Table 3: Selected interview responses to limitations

Question What is the main limitation or internal
factors your firm faced in pursuing business growth in the SME sector?

Selected responses are so many people involved, few
thousands of employees that you're talking
about and external investors. So, there will
be reformers who wants transformation.
Okay, but it's obviously met with, how do you
say, resistance from old time employees and
also the pioneers who are still around.
(Interviewee D, Head of Technical
Operations)
"So, when clients approach us or when you
approach clients based on for specific
innovation, the actual product is either not
yet available, or is not available to many. So
many clients are, they have this doubt that
local tech companies can actually do."
(Interviewee B, Firm Owner)


c) SE Practices
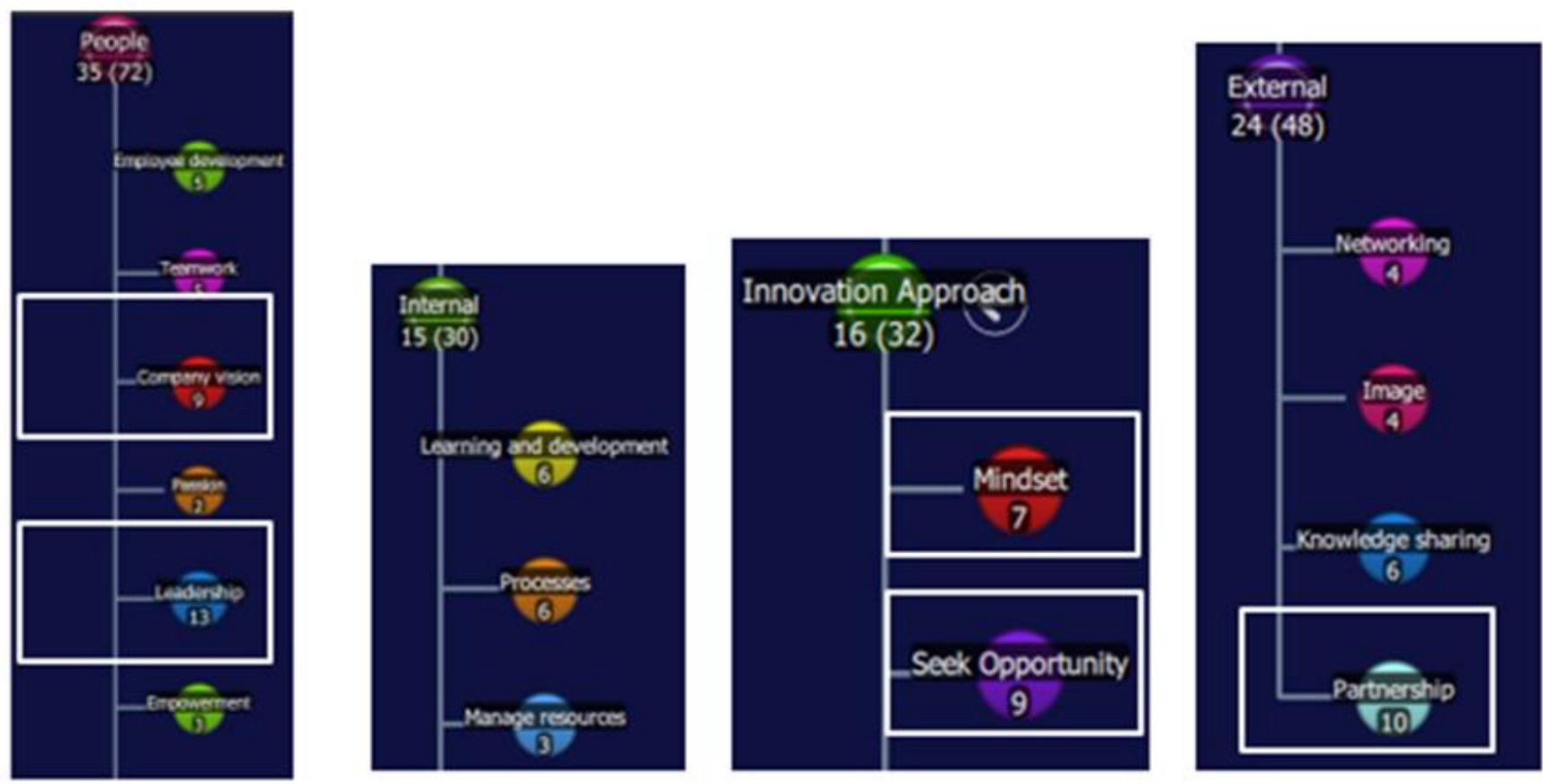

From the graphical representation of the interview data (Figure 3), there are 90 codes related to the current practices of SE at the SME firms. The main elements of the SE framework are People, Internal, Innovation Approach and External which are categorized as the main themes. People element is the most referred to by the research participants with 35 occurrences, followed by External element, Innovation Approach and Internal elements respectively. The top 2 most important SE areas under the People element are Leadership and Company Vision. A total of 13 leadership-related occurrences emphasize how organizational goals must be clear and employees must work towards achieving the goals. Few of the related responses are presented in Table 4. External element plays a major role amongst SME players in terms of fostering cooperation with technological partners to expedite technology development and expand business opportunities. Also significant is the Innovation Approach involving seeking opportunities within the market at all times. Creating innovation in their products and services is key to business growth. This is along with strong mind-set to promote technology and having the foresight to position their technology within the right market. 
Table 4: Selected Interview Responses to SE Practices

\begin{tabular}{|c|c|}
\hline Question & $\begin{array}{l}\text { What are the main strategic entrepreneurship } \\
\text { practices currently practiced in your organization? }\end{array}$ \\
\hline Selected responses & $\begin{array}{l}\text { "And that is where I think I'm very fortunate to be } \\
\text { working under this director, which I feel that he } \\
\text { always has the foresight, he doesn't wait until it's } \\
\text { time to innovate then he innovates, he calls for the } \\
\text { innovation even before it." (Interviewee D, Head of } \\
\text { Technical Operations) } \\
\text { "So, because everything that I've learned so far, it's } \\
\text { all about leadership, you know, goal setting, } \\
\text { somebody has got to be the visionary, and } \\
\text { somebody has got to set the goals and whatnot, so } \\
\text { that the rest can actually have something to follow } \\
\text { by." (Interviewee E, Director) } \\
\text { "Selain daripada itu salah satu benda yang penting } \\
\text { sebagai leader, kita kena cepat bertindak. Once } \\
\text { business is down, kita berani untuk ambil risiko } \\
\text { untuk change business." [Apart from that, the } \\
\text { important attributes as a leader is to be able to } \\
\text { respond swiftly when the business is down and } \\
\text { have the courage to take risks to change the } \\
\text { business direction] (Interviewee A, Managing } \\
\text { Director) }\end{array}$ \\
\hline
\end{tabular}

d) SE Framework

From the data analysis, it can be seen that all elements within the conceptual framework introduced earlier are present within the current SME practices in Malaysia. Although People, Internal and Innovation Approach elements are consistent with the elements in Kyrgidou \& Hughes (2010) SE model, the External element suggests to be particularly significant in Malaysian SME arena. This study concludes with a representation of the elements confirmed within the SE framework in Figure 4. The keywords indicated in each quadrant have been revised from the earlier conceptual framework to represent areas that had resonated strongly with the research participants. This final framework, termed as the PIIE Entrepreneurial Model, illustrates four quadrants with each representing a key SE element. 


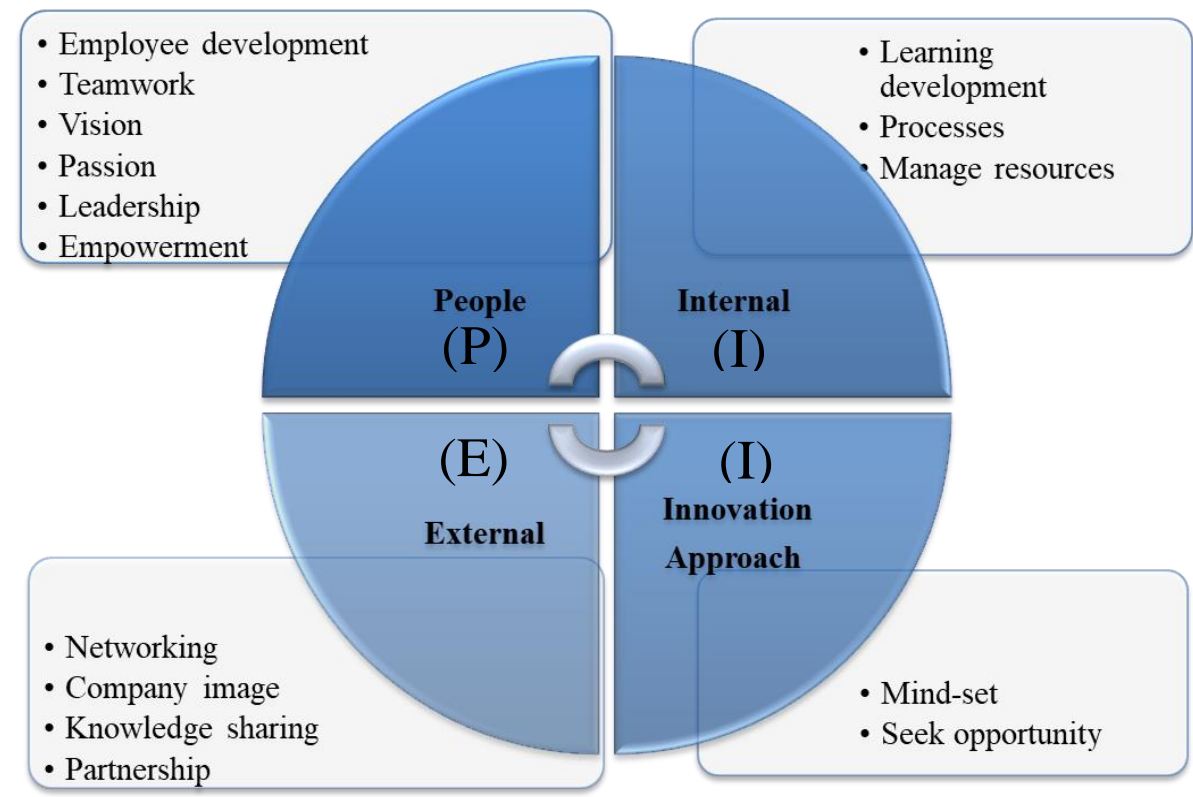

Figure 4: PIIE Entrepreneurial Model

\section{Conclusion}

a) Research Outcome

In order to identify the SE practices that are important to an SME business performance, it was also important to understand the related challenges and limitations. To grasp the fundamental of SE, the two constructs of entrepreneurship and strategy were identified as (i) applying innovative and creativity to seek opportunity and (ii) taking advantage of the opportunity created to promote business growth, respectively. Based on the Kyrgidou \& Hughes (2010) model and the components within the Ireland et al (2003) SE linear model, a conceptual framework consisting of key SE elements was developed for this study. These elements were identified as People, Internal, Innovative Approach and External. It was noted that the External element had been included into the framework in view of the developing nature of Malaysian SME market and technology industry. Based on the SME Integrated Plan of Action, the Malaysian government has allocated an extensive amount of budget to undertake SME development programs to spur high growth and innovation technologies as well as to contribute to high potential sectors such as rail industry, medical devices, aerospace, automotive, digital economy, biotechnology and renewable energy (Govt allocating significant resources to support SME growth, technological adoption, 2019).

The data findings revealed that all SE elements in the conceptual framework are relevant and present in the engineering and technology-based companies in Malaysia. People element is commonly recognized as important since leaders with strong leadership skills are seen to keep the firm focused on achieving its goals. Leaders' attitude of being able to take risks and always open to other possibilities are also important in seeking opportunities and taking advantage over certain situations. Most of the SME leaders also opined that managing their external environments has impacted their business performance growth. Companies that deal with evolving technologies especially feel the need to network with government agencies to keep policies in check. They also realize the importance in cooperating with technology and business partners to increase chances of technology breakthroughs while seizing business opportunities. Setting up business cooperation with other reputable firms will help SME firms to overcome their lack of resources and achieve growth in the market, 
especially when facing other competitive and larger firms within the market (Franco \& Haase, 2020).

There are two key areas within Innovation Approach, one of it is the ability to seek opportunities according to the current situations. The current pandemic situation has pushed business owners to re-evaluate their low profit-making products and services to others that can take advantage of the situation. The other key area is having an innovative and creative mind-set especially in finding business opportunities and diversifying products or services. The internal-related factors also exist, albeit lower mentions recorded from the research participants, still pose significance in areas such as learning and development. Creating continuous learning environment through on-the-job training and training for employees are activities commonly propagated by the research participants.

\section{b) Recommendation}

The limitations faced by the engineering and technology-based SME companies were mainly related to manpower, where one of the common points highlighted was generation gap within the organizations. Most of the leaders expressed their concern on the communication and collaboration gap between the older and younger generation of employees. This may be an increasing concern affecting organizational behavior which may also affect business performance. Conflicts arising from negative stereotyping of millennials by other generations may be due to differences in attitudes and conflicting values of different generations (Millennials create conflict at work because they feel "hurt" by unfair attitudes of superiors, 2018). This emerging issue must be addressed holistically due to the possible stereotyping of millennials' generic dispositions. Thus, suggestions on countermeasures that specifically address the bridging of gaps between different generations are necessary.

The financial challenges faced by the research participants mostly touched on difficulties in obtaining grants and having to fund their own businesses. It was also informed in one of the interview sessions that the grant provider was not able to fully grasp the newly proposed technology to appreciate SME business' needs. This also relates back to the point highlighted by an interviewee who is unaware of existing official platforms for SME firms to discuss their issues. Most research participants replied that they use unofficial social platforms to share their grievances and experiences with fellow SME firm owners. The research participants also acknowledged the importance of sharing knowledge amongst SME business counterparts. There have been various financing collaboration efforts by financing institutions that have been put in to drive technology and innovation for SMEs (SME Corp Malaysia, 2019). Notwithstanding this, more study may be required to assess the extent of outreach and effectiveness of such existing programs provided by official bodies since SME firm owners still think that this area is lacking and inaccessible to them.

\section{c) Research Contribution and Limitation}

The theoretical contribution of this study is in terms of knowledge advancement within the field of SE where the PIIE Entrepreneurial Model represents four SE important elements in pursuing SME business growth. In addition, the insights from this study can also be used for policy makers to further understand the practical side of the SE process in order to develop more relevant and effective SME-related policies that can stimulate the SME economy. On the other hand, this study also offers contextual contribution through the implications of the PIIE Entrepreneurial Model on an SME set-up. SME strategy practitioners or firm leaders can reduce the gaps in their SE process by applying or enhancing any of the 
suggested SE elements that they are lacking of. In order to compete with larger firms, smaller SME firms may focus towards capturing more opportunities created through partnerships or heightened engagement with external parties or government agencies. However, due to lack of resources, this study is presented with limitations. Since the conceptual framework presented in this study had been tested on a small group of research participants within a specific sector, it would be more engaging if the framework is tested to see if it also applies in larger groups of research participants, as well as in other sectors in order to see if similar results emerge.

\section{References}

Arbussa, A., Bikfalvi, A., \& Marquès, P. (2017). Strategic agility-driven business model renewal: the case of an SME. Management Decision, 55(2), 271-293.

Barringer, B. R., \& Ireland, D. R. (2012). Entrepreneurship: Successfully Launching New Ventures, 4th Edition. Pearson/Prentice Hall.

Clegg, B. (2018). Perceptions of growth-impeding constraints acting upon SMEs' operations and the identification and use of transitionary paths to elevate them. International Journal of Operations \& Production Management, 38(3), 756-783.

Crockett, D. R., Payne, T. G., \& McGee, J. E. (2007). Exploitation of entrepreneurial opportunities in the corporation: an exploration of functional-level support, decision anatomy, and performance. (G. Lumpkin, \& J. A. Katz, Eds.) Entrepreneurial Strategic Process, 10, pp. 33-63.

DeMartino, R., Sriramachandramurthy, R., Miller , J. C., \& Angelis, J. N. (2015). Looking Inside the Black Box of Growth Efforts in Declining Small Firms; The Role of Growth Factors, Planning, and Implementation. Advances in Entrepreneurship, Firm Emergence and Growth, Volume 17,, 17, 265-296.

Department of Statistics Malaysia. (2019). Retrieved from Small and Medium Enterprises (SMEs) Performance 2018:

https://www.dosm.gov.my/v1/index.php?r=column/cthemeByCat\&cat=159\&bul_id= ROVka2RpeVJ0cUlpR3BqdjhudDZhdz09\&menu_id=TE5CRUZCblh4ZTZMODZIbmk2aW RRQT09

Fabian, F., \& Ndofor, H. A. (2007). The context of entrepreneurial processes: one size does not fit all. (G. Lumpkin, \& J. A. Katz, Eds.) Entrepreneurial Strategic Process, pp. 249279.

Franco, M., \& Haase, H. (2020). The role of reputation in the business cooperation process: multiple case studies in small and medium-sized enterprises. Journal of Strategy and Management, 14(1), 82-95.

Gaddefors, J., \& Anderson, A. R. (2017). Entrepreneursheep and context: when entrepreneurship is greater than entrepreneurs. International Journal of Entrepreneurial Behavior \& Research, 23(2), 267-278.

Govt allocating significant resources to support SME growth, technological adoption. (2019). Retrieved from The Sun Daily: https://www.thesundaily.my/local/govt-allocatingsignificant-resources-to-support-sme-growth-technological-adoption-DL836137

Haddad, M. I., Williams, I. A., Hammoud, M. S., \& Dwyer, R. J. (2020). Strategies for implementing innovation in small and medium-sized enterprises. World Journal of Entrepreneurship, Management and Sustainable Development, 16(1), 12-29. 
Hanifah, H., AbdulHalim, H., Ahmad, N., \& Vafaei-Zadeh, A. (2019). Emanating the key factors of innovation performance: leveraging on the innovation culture among SMEs in Malaysia. Journal of Asia Business Studies, 13(4), 559-587.

Heikkilä, M., Bouwman, H., \& Heikkilä, J. (2018). Journal of Small Business and Enterprise Development. Journal of Small Business and Enterprise Development, 25(1), 107-128.

Industry4WD. (2020). Retrieved from Ministry of International Trade and Industry: https://www.miti.gov.my/miti/resources/National\%20Policy\%20on\%20Industry\%20 4.0/Industry4WRD_Final.pdf

Ireland, D. R., Hitt, M. A., \& Sirmon, D. G. (2003). A Model of Strategic Entrepreneurship: The Construct and its Dimensions. Journal of Management, 29(6), 963-989.

Kamel, H. (2019). The Malaysian Reserve. Retrieved from Local SMEs contribution to 2020 GDP is low, says deputy finance minister:

https://themalaysianreserve.com/2019/12/13/local-smes-contribution-to-2020-gdpis-low-says-deputy-finance-minister/

Kyrgidou, L. P., \& Hughes, M. (2010). Strategic entrepreneurship: origins, core elements and research directions. European Business Review, 22(1), 43-63.

Li , L., Ci, J., \& Gao, X. (2012). The Growth Evaluation Model of Manufacturing SMEs and Application from System Engineering Perspective. Systems Engineering Procedia, 5, 412-419.

Luke, B., Kearins, K., \& Verreynne, M.-L. (2011). Developing a conceptual framework of strategic entrepreneurship. Entrepreneurial Behaviour \& Research, 17(3), 314-337.

Lumpkin, G. T., \& Katz, J. A. (Eds.). (2007). Entrepreneurial Strategic Processes. JAI Press Inc.

Millennials create conflict at work because they feel "hurt" by unfair attitudes of superiors. (2018). Human Resource Management International Digest, 26(2), 36-37.

Quirkos 2.4.2 [Computer Software]. (2021). Retrieved from https://www.quirkos.com

SME Annual Report. (2020). Retrieved from SME Corporation Malaysia: https://www.smecorp.gov.my/images/SMEAR/SMEAR2018_2019/final/english/SME \%20AR\%20-\%20English\%20-\%20All\%20Chapter\%20Final\%2024Jan2020.pdf

SME Corp Malaysia. (n.d.). Retrieved from SME Definition: http://www.smecorp.gov.my/index.php/en/policies/2020-02-11-08-01-24/smedefinition

SME Corp Malaysia. (2019). Retrieved from Towards engineering growth of businesses: https://www.smecorp.gov.my/index.php/en/resources/2015-12-21-10-5522/news/3825-towards-engineering-growth-of-businesses-2

Sun, S. L., Xiao, J., Zhang, Y., \& Zhao, X. (2018). Building business models through simple rules. Multinational Business Review, 26(4), 361-378.

Verreynne, M.-L., \& Meyer, D. (2007). Modeling the role of intrapreneurial strategy-making in small firm performance. (G. Lumpkin, \& J. A. Katz, Eds.) Entrepreneurial Strategic Process, 10, pp. 103-130.

Wei, Y. L., Long, D., Li, Y. K., \& Cheng, X. S. (2018). Is business planning useful for the new venture emergence? Chinese Management Studies, 12(4), 847-870. 